\title{
Measuring Social Capital Linkage: The Role of the State-Based Voluntary Professional Association
}

\section{Christopher Lowe}

\begin{abstract}
This paper discusses the nature of the Australian bus and coach representative environment and the role of the state-based voluntary professional association (SBVPA). A literature review associated with memberships to which businesses subscribe for representation and linking social capital is presented, as well as a discussion on agency theory that possibly explains the member/association dynamic. The results of an Australia-wide survey of bus operators, which measures the extent of linking social capital between themselves and their SBVPA, are revealed. It is found that one state with consistently higher results may possess a competitive advantage in the form of a partnership agreement with the State Government Authority-an agreement that rests on co-operation and facilitates social capital. This evidence could contribute to the global narrative on how non-profit associations can be a mechanism for institutionalising social capital, sustain a firm's operation and encourage governments to increase their use of non-profit associations, as agents of government, to achieve public policy outcomes.
\end{abstract}

\section{Keywords}

Voluntary professional association, bus operators, linking social capital

In Australia, most bus operators with a government-funded bus-service contract belong to a state-based voluntary professional association (SBVPA) principally because of a long-held custom of Australian State Governments to procure some bus-services via a negotiated process involving the SBVPA as the representative of the collective operators in each state. However, little is known about the role of the SBVPA. Further, nothing appears to be published or known about the operators' views of their SBVPA and how, if at all, the SBVPA impacts their business and whether operators' views are consistent across each Australian jurisdiction or not. Importantly, very little is known about what literature and theories might explain the operator/association dynamic and whether there is any evidence that provides a link between theory and practice. This paper contributes toward filling this knowledge gap.

This paper is structured as follows. After defining linking social capital in Section 2, Section 3 discusses the nature of the Australian bus and coach representative environment and the role of the SBVPA, with a special focus on Victoria. A literature review associated with both memberships to which businesses subscribe for representation and linking social capital features in Section 4, along with the

\footnotetext{
aMonash Sustainability Institute, Australia

Correspondent Author:

Christopher Lowe, 450 Graham Street, Port Melbourne, VIC 3207, Australia

E-mail: clowe@busvic.asn.au
} 
nomination of agency theory as a theoretical framework that seems to underpin the member/association dynamic. Section 5 presents this paper's two research questions and the research methodology adopted, and Section 6 presents the results. Section 7 features a discussion on the meaning and implications of the results and Section 8 draws conclusions.

This paper hopes to make a contribution to knowledge in two areas: How linking social capital (or social capital linkage) between an association and its members might improve the extent of involvement and dependence between them; and how non-profit associations, as facilitators of social capital linkage, might sustain a firm's operation and be increasingly used as agents of government to achieve public policy outcomes.

\section{DEFINITION}

There are many forms of social capital. This study adopts Putnam's (1995) overarching definition of social capital as the development of reciprocity, social networks, and trust between people. This paper focuses on social capital linkage, which Putnam (1995) refers to as the connection between individuals and groups in different social settings in a hierarchy where status and wealth are accessed. This includes the capacity to leverage resources, ideas, and information from formal institutions beyond the community, such as a bus operator's SBVPA.

\section{THE NATURE OF THE AUSTRALIAN BUS AND COACH REPRESENTATIVE ENVIRONMENT}

There are eight primary voluntary professional associations in the Australian bus and coach representative environment. Victoria, New South Wales, South Australia, Queensland, Tasmania, and Western Australia all have SBVPAs for bus and coach operators. The Bus Industry Confederation (BIC) is the federal industry body and by virtue of its location in Canberra, it assumes the task of representing the industry to the Government of the Australian Capital Territory. The Australian Public Transport Industrial Association (APTIA) represents and assists its members in matters relating to the settlement of industrial disputes between members and their employees and promotes and protects the interests of employers within both the publicly and privately owned passenger transport industry.

The remit of the six SBVPAs is to represent their members' best interests to respective state and territory governments on matters including service contract negotiation, state-based industrial relations, legislative and regulatory compliance, education (mainly through conferences, exhibitions, and seminars), and public safety. Most SBVPAs offer their members products or services, such as purchasing incentives on fuel, insurance, and finance. All of the SBVPAs do this to varying extents.

The federal voluntary professional association, BIC, represents the interests of its members to the federal government on a range of issues, including technical vehicle and parts-based issues and the broader challenge of meeting the growing passenger transport task and providing Australian commuters with a genuine alternative to the car. The BIC is primarily a policy development organisation that commends such policies to local, state, and federal governments. The APTIA is the industrial arm of BIC.

There are secondary SBVPAs in both Queensland and Western Australia, but as they have a smaller number of member operators and are not actively involved in the industry's collective representative endeavours, their input has not been sought for this paper. There are also peripheral, like-minded voluntary professional associations to which some bus operators and/or SBVPAs belong, such as UITP (the International Association for Public Transport, from 
the French L'Union Internationale des Transports Publics) and the Australian Railways Association. The remit or views of these two organisations is not included in this paper.

Each of the six SBVPAs has their own constitution and board; each has its own methods (or formulae) for levying members and operates completely independently. There are no scale economies or shared services between the six SBVPAs, but there are some scale economies in the form of shared services between the BIC and APTIA. The potential for more shared services and the achievement of scale economies between all eight associations is currently a focus of the industry due to operator consolidation.

The Victorian SBVPA is acknowledged as being unique in the bus and coach representation environment. Its employee headcount and turnover is markedly larger than that of the other SBVPAs and the BIC. Its research agenda centres on quadruple bottom-line (social, economic, environmental, and governance) issues that it commends to government and other industry representative bodies to show how increased resources for public transport can help to alleviate societal issues, such as urban congestion, public health, emissions and social inclusion, and improve the efficiency and effectiveness of the services in the communities in which its members operate a transport service. The Victorian SBVPA also owns several commercial entities that sell products and services to its member operators, which enables them to fulfil their contractual and regulatory obligations, such as bus inspections (roadworthy certificates), spare parts and accessories, finance and comprehensive insurance. Anecdotally, member operators show a high degree of loyalty to the commercial endeavours of their SBVPA. The Victorian SBVPA has also been contracted to the Victorian Government over the years to work as its agent to deliver on some of its objectives such as reducing fare evasion, implementing the ticketing system, improving service time tabling, and marketing the network.

The primary task of most SBVPAs is to negotiate selected bus-service contracts on behalf of their member bus operators. From one perspective, the SBVPA acts as a conduit between bus operators and the procuring government authority in undertaking this task. In this circumstance, the SBVPA actually has reciprocal obligations. First, as a representative of the operator, the SBVPA can ensure that government affords the operator contractual fairness and operating continuance, which enables the operator to sustain or improve its community interaction and other non-economic goals. Second, as an agent of government, the SBPVA can marshal contracted bus operators in order to realise contract compliance and work toward the achievement of public policy outcomes. The benefit to governments in using this method is that they need only engage with one organisation to renew bus-service contracts, rather than engage with every contracted operator or their commercial and/or legal representatives. This keeps government transaction costs associated with bus-service procurement under control. The benefit to the operator is that they receive a template bus-service contract whose rights and obligations do not differ to other operators' service contracts. The bus-service contract has also been the subject of discussion and determination by a committee of members within the SBVPA charged with the responsibility of ensuring the contract clauses are fair and practical and have the flexibility to allow ongoing dialogue about current and future issues in the operating environment. The theory of incomplete contracts (Hart and Moore 1990) suggests parties are unable to write complete contingent contracts. Such processes are entirely consistent with agency theory-the bus operator (as the principal) delegates authority to the SBVPA to sustain their contractual relationship with the State Government, which is acceptable to both buyer and seller. 


\section{LITERATURE REVIEW AND THEORETICAL OFFERING}

This section reviews the literature concerning the memberships to which family businesses and non-family businesses subscribe, as it is central to understanding if other industries have found support for the voluntary professional association (or industry not-for-profit), contributing to sustaining firms and their ability to contribute to the community in which they operate.

Lester and Cannella (2006) suggested community-based social capital enhanced through membership in a community of, for example, founder-led firms, professional service organisations, or non-profit entities, if linked to compensation practices and norms across those communities, might open up a multitude of new avenues for research. Parada, Nordqvist, and Gimeno (2010) discussed the role of voluntary professional associations defined as organisations created to represent business interests within specific domains, mobilising the firms within these areas so that collective action can be taken to address common problems. The Bus Association Victoria Inc. (2015) website states that its role is to form, spread, and legitimise the adoption of guiding business values as a specific type of governance practice. It also suggests that it is part of the industry's social capital, an assertion that is consistent with Parada et al. (2010).

Carney (2005) asserted social preferences and factors such as ethnicity are more significant in the context of the family firm. This is relevant to the narrative as most bus operators in Australia are family firms. Transactions stemming from membership in social networks tend to rest upon one of several "axes of solidarity", such as kinship, ethnicity, community, and political affiliation, which form the basis for interpersonal trust. Such transactions may be associated with unspecified obligations and reciprocity over uncertain time horizons. Carney
(2005) suggested social capital generates value for a firm because it reduces transaction costs relating to search, screening, adjustment, and contract enforcement, and that it is probable that the efficiency advantages of family governance diminish with large firm size. The author also argues business groups that have extensive social capital can influence the political agenda, capture policy initiatives, and reverse institutional developments that generate competition from new entrants. These factors suggest that family-owned firms tend to be disadvantaged in implementing strategies that require extensive research and development investments and complex coordination systems. Having an industry representative body that invests in both research and development and coordinates systems-not necessarily in the immediate geographic community, but on behalf of a "community of interest" or collective of like-minded family businesses_-provides two centrally co-ordinated tasks that benefit the collective. By organising activities such as courses, programmes, and seminars, voluntary professional associations represent a space where family business stakeholders can socialise and engage in training, thereby sharing knowledge, developing cultural understanding, and fostering personal individual development (Jarvis 1987).

Parada et al. (2010) demonstrated how institutional champions can lead the process of changing values in family businesses from their position as a social bridge between the family-firm and institutional levels. The Bus Association Victoria Inc. (2015) website declares it is owned and controlled by its members and it applies "co-op" principles and values as part of its modus operandi; it is perceived as a co-operative by members and the public alike. Although classified as an incorporated association, its remit is aligned to that of a co-operative. A co-operative is a social enterprise that aims to generate and reinvest profits necessary to sustain or grow the business while also providing low prices and 
improved services to members, which in turn engenders high levels of loyalty and commitment. Social enterprises trade to create social value, whether it is to serve members better, to generate community benefit, or to trade more ethically. Social enterprises share prosperity with all of their stakeholders-members, customers, employees, and the community; they make profit (or surplus) in the service of their social goals. Bus Association Victoria owns several entities that facilitate agglomeration to add value to members' pricing and to remain competitive.

Consistent with the above, Bryce (2012) suggested that unlike a firm, the non-profit is a public or social asset. It does not belong to a group of investors. Therefore, the issues of social accountability, responsibility, and control are inherent in the principal-agent paradigm as applied to the non-profit as an agent of public policy. Bryce (2012) suggested:

(1) Non-profits foster, formulate, perform, and evaluate society's policies that are in the furtherance of the public good and inherent in this relationship is the concept of the non-profit acting as an agent of public policy;

(2) Social capital and non-profits affect the performance of entities involved in a myriad of major market transactions as a matter of public policy;

(3) Non-profits facilitate collective action for government by using the networks, interactions, trust, and reciprocity of their members;

(4) The industry's social capital is what binds the members of the association, fostering a common trust that induces co-operation and therefore collective action.

Definitions of social capital vary, but the main aspects include citizenship, "neighbourliness", social networks, and civic participation. Linking social capital, describes connections with people in positions of power and is characterised by relations between those within a hierarchy where there are differing levels of power; it is good for accessing support from formal institutions. It is different from bonding social capital and bridging social capital in that it is concerned with relations between people who are not quite on an equal footing, like an operator's SBVPA whose remit is to maintain clear, open, and frequent dialogue with the authority and achieve outcomes for its members. In Australia, many operators would request their SBVPA to represent their interests to the authority. In this circumstance, linking social capital reflects the dynamic between the operator and the SBVPA to achieve an outcome with the authority.

Early perspectives on social capital came from Bourdieu (1986), Coleman (1988), Putnam (1995), and Portes (1998). Several scholars have written of the link between social capital and the contribution business makes to regions, but none of them appear to identify and quantify the associated social externalities, which the writer does in his doctoral research project (Lowe 2015). The role of social capital linkage between an operator and its SBVPA could be a predictor variable of an operator's propensity to interact with its community; hence, it requires attention in this literature review.

Laursen, Masciarelli, and Prencipe's (2012) study is relevant to this paper because it identifies geographically localised social capital as a key factor in promoting firm-level innovation, and provides quantitative evidence to support this finding. Their research is reinforced by Bell and Kilpatrick (2000), who examine the contribution small businesses make to regional Tasmania, beyond their economic contribution. Green (1996) examined the importance of social capital on entrepreneurship and family-business development in rural communities. The author's research is directly related to this paper, because $89 \%$ of Victoria's bus operators are located outside of metropolitan Melbourne (personal communication, June 2015). Murphy (2005) suggested that with limited finances, staffing, and expertise, smaller firms cannot compete with the larger, better-resourced organisations responding to 
government tenders. This suggestion is reinforced in Winter (2000). This is where the SBVPA adds value to the operators' desire for continuance to sustain their contribution and the viability and prosperity of their community. Australian state governments have historically negotiated various forms of template bus-service contracts with SBVPAs as representatives of the collective operators and delivered purchasing incentives that keep member operators' costs competitive. These products and services do build on the extent of social capital linkage between operators and their SBVPA and could build on the extent of bonding and bridging social capital. Importantly, however, Cox and Caldwell (2000) suggested the present direction of some governments toward tendering-out may be a major factor at the falling levels of trust in governments.

\section{Theory}

Agency theory appears to explain the dynamic between the bus operator and the SBVPA. The bus operator (as the principal) delegates authority-in terms of control and decision-making about certain tasks - to another party, which in this context is the SBVPA (the agent). When the agent is acting for the principal, it resembles behaviours such as performing for the benefit of the principal or acting as the principal's representative (Fayezi, O’Loughlin, and Zutshi 2012). Agency theory assumes that people pursue their own self-interests and expect others to behave in the same way.

As a practitioner, the author has observed there to be a multitude of tasks that the SBVPA undertakes as the agent of a bus operator member of the SBVPA (the principal). The primary task of each bus and coach SBVPA for at least the last 30 years has been to negotiate bus-service contracts with state governments, as an agent of the collective operators. Anecdotally, this sees the operators place their trust in the competency of the SBVPA negotiators to reach an outcome with government whereby the operators achieve business continuity and a fair reward for the contracted task. Another task of the SBVPAs has been to negotiate template industrial instruments (e.g., Enterprise Agreements and Workplace Agreements) with unions, which are then commended to operators for implementation. Members of SBVPAs also expect their SBVPA to act as an agent to resolve operating issues that have the potential to affect the collective operators, particularly on matters that concern driver and passenger safety, technical requirements, contract disputes and legislative and regulatory interpretations.

Contributions by scholars such as Ross (1973), Mitnick (1973), Jensen and Meckling (1976), and Eisenhardt (1989) demonstrate agency theory's relationship with the economic realm. Other scholars have investigated agency theory as it relates to disciplines such as finance, information systems, management, supply chain management (Ritchie, Brindley, and Armstrong 2008) and sociology (Shapiro 1987; Shapiro 2005). Agency theory seems to explain how the relationship between the SBVPA member operator (the principal) and the SBVPA (the agent) might influence bus-operator governance models to achieve certain levels of community interaction.

\section{STUDY QUESTIONS AND METHODOLOGY}

This paper asks two questions:

(1) What extent of impact does membership of an SBVPA have on a bus operator's ability to run its business?

(2) How do operators rate their SBVPA's effectiveness on the following five determinants (taken from assertions made in the literature) and information provided by the Victorian SBVPA (Foote 2015) which lists in order of importance, members' priorities for belonging and the benefits of same:

(a) The extent to which the SBVPA gives operators access to buying power that helps them compete;

(b) The extent to which the SBVPA helps 
operators secure better contract terms and conditions;

(c) The extent to which the SBVPA enhances the operators' ability to interact with their community in the eight ways defined in the author's doctoral research project (Lowe 2015);

(d) The extent to which operators use the SBVPA as a forum to share ideas, network and build inter-operator trust;

(e) The extent to which the SBVPA fosters good relationships with the state government and the opposition.

These questions and answers are drawn from the author's doctoral research project (Lowe 2015). A survey entitled "Bus Operators' Community Interaction Survey” (the Survey) was developed and distributed to 1,623 bus and coach operator members of the six SBVPAs and some operator members of the BIC that were not members of the SBVPAs. This number represents approximately $30 \%$ of all bus operators in Australia. The survey received a 13\% response rate, which is deemed adequate for undertaking statistical analysis on an overall (national) basis and inadequate for state/territory specific analysis on South Australia and the Australian Capital Territory. The survey asks 29 questions seeking qualitative and quantitative answers in five sections. This study draws evidence from Section 3 of the survey, which asked operators for their views of the role of the SBVPA and the extent to which it contributes toward the industry's social capital (see APPENDIX). When the surveys were returned, all quantitative information was entered into SPSS ${ }^{\mathrm{TM}}$ (v.20, IBM, USA). The quantitative information was analysed using SPSS, and the results were exported into Excel for conversion into various table and graph formats and then copied into Word for ease of presentation.

\section{RESULTS}

This section presents empirical evidence that provides a bridge between the literature and the methodology.
All results are presented in a series of tables and one figure. One-way ANOVA and Pearson chi-square contrast testing methods were adopted to test whether the results are statistically significant (i.e., the results did not eventuate by chance). All contrast test results that are statistically significant are highlighted in green and labelled with either “*”, or “**”. Results from South Australia are to be ignored.

\section{Question 1}

Question 1 is answered by cross-tabulating Survey Q.25 with Survey Q.6 (primary state of operation). The analysis reveals that on a state-specific basis, the Tasmanian SBVPA received the highest percentage of "very positive impact" with $61.9 \%$ (of 21 respondents), followed by Victoria with 48.9\% (of 92 respondents) and Western Australia with 46.7\% (of 45 respondents). Tasmanian and Victorian Survey respondents rated their SBVPA as having the highest impact on their business-it should also be noted that the governments of these two states have to date typically negotiated the renewal of their bus-service contracts. These results are presented in Table 1.

\section{Question 2}

Question 2 is answered by cross-tabulating Survey Q.26(a), (b), (c), (d), and (e) responses, firstly in turn, against state of operation (from Survey Q.6), then, in aggregate by using the combined overall responses to Survey Q.26 [i.e., the combined responses to Q.26(a), (b), (c), (d), and (e)], according to state of operation (from Survey Q.6). Then the contrasts between states for Survey Q.26 combined overall are tested using one-way ANOVA.

\section{Survey Question 26(a)}

Table 2 presents the results for Q.26(a), “My SBVPA gives my firm access to buying power that helps my firm compete", and Table 3 shows the Pearson chi-square contrast test, the result of which is statistically significant. 
Table 1. Cross-Tabulation of Q.25 $\otimes$ Q.6 Primary State, in Relative (i.e., Percentage) Terms

\begin{tabular}{|c|c|c|c|c|c|c|c|c|}
\hline & & \multicolumn{6}{|c|}{ Primary state } & \multirow{2}{*}{ - All $(\%)$} \\
\hline & & VIC (\%) & NSW (\%) & QLD (\%) & TAS (\%) & SA (\%) & WA (\%) & \\
\hline \multirow{5}{*}{$\begin{array}{l}\text { Q.25 Impact of } \\
\text { association on } \\
\text { operator } \\
\text { businesses }\end{array}$} & 1. Very positive impact & 48.9 & 31.9 & 25.0 & 61.9 & 40.0 & 46.7 & 42.6 \\
\hline & 2. Generally positive impact & 38.0 & 49.3 & 50.0 & 28.6 & 20.0 & 33.3 & 40.2 \\
\hline & $\begin{array}{l}\text { 3. Neither negative nor } \\
\text { positive impact }\end{array}$ & 12.0 & 18.8 & 20.8 & 9.5 & 40.0 & 20.0 & 16.4 \\
\hline & 4. Generally negative impact & .0 & .0 & 4.2 & .0 & .0 & .0 & .4 \\
\hline & 5. Very negative impact & 1.1 & .0 & .0 & .0 & .0 & .0 & .4 \\
\hline Total & & 100.0 & 100.0 & 100.0 & 100.0 & 100.0 & 100.0 & 100.0 \\
\hline
\end{tabular}

Notes: VIC-Victoria; NSW-New South Wales; QLD-Queensland; TAS-Tasmania; SA-South Australia; WA-Western Australia.

Table 2. Cross-Tabulation of Q.26(a) Access to Buying Power $\otimes$ Q.6 Primary State, in Relative (i.e., Percentage) Terms

\begin{tabular}{lllllllll}
\hline & \multicolumn{9}{c}{ Primary state } \\
\cline { 3 - 8 } & & VIC (\%) & NSW (\%) & QLD (\%) & TAS (\%) & SA (\%) & WA (\%) & All (\%) \\
\hline \multirow{3}{*}{$\begin{array}{lllll}\text { Q.26(a) Access } \\
\text { to buying }\end{array}$} & 1. Strongly agree & 9.8 & 4.5 & 4.3 & 25.0 & .0 & 13.6 & 9.6 \\
power & 2. Agree & 42.4 & 25.8 & 13.0 & 45.0 & 20.0 & 31.8 & 33.2 \\
& 3. Don't agree or disagree & 37.0 & 40.9 & 39.1 & 20.0 & 40.0 & 40.9 & 37.6 \\
Total & 4. Disagree & 8.7 & 21.2 & 21.7 & 10.0 & .0 & 4.5 & 12.4 \\
\hline
\end{tabular}

Table 3. Pearson Chi-Square Contrast Test Pursuant to Table 2

\begin{tabular}{llll}
\hline & Value & df & Asymp. sig. (2-sided) \\
\hline Pearson chi-square & 46.766 & 20 & $.001^{* *}$ \\
N of valid cases & 250 & & \\
\hline
\end{tabular}

Note: ${ }^{* *}$ means statistically significant at the $1 \%$ level.

Table 4. Cross-Tabulation of Q.26(b) Secure Better Contract Terms x Q.6 Primary State, in Relative (i.e., Percentage) Terms

\begin{tabular}{lllllllll}
\hline & \multicolumn{9}{c}{ Primary state } \\
\cline { 3 - 8 } & & VIC (\%) & NSW (\%) & QLD (\%) & TAS (\%) & SA (\%) & WA (\%) & \\
\hline \multirow{3}{*}{$\begin{array}{l}\text { Q.26(b) Secure } \\
\text { better contract }\end{array}$} & 2. Agree & 52.7 & 29.2 & 12.5 & 28.6 & .0 & 54.5 & 40.1 \\
terms & 4. Don't agree or disagree & 10.8 & 16.9 & 37.5 & 9.5 & 60.0 & 13.6 & 16.3 \\
& 4. Disagree & .0 & 6.2 & .0 & 9.5 & .0 & 6.8 & 3.6 \\
Total & 5. Strongly disagree & 3.2 & 6.2 & 8.3 & .0 & .0 & 2.3 & 4.0 \\
\hline
\end{tabular}

Table 5. Pearson Chi-Square Test Pursuant to Table 4

\begin{tabular}{llll}
\hline & Value & df & Asymp. Sig. (2-sided) \\
\hline Pearson chi-square & 47.250 & 20 & $.001^{* *}$ \\
N of valid cases & 252 & & \\
\hline
\end{tabular}

Note: ${ }^{* *}$ means statistically significant at the $1 \%$ level. 


\section{Survey Question 26(b)}

Table 4 presents the results for Q.26(b), "My SBVPA helps my firm secure better contract terms and conditions", and Table 5 shows the Pearson chi-square test, the result of which is statistically significant.

\section{Survey Question 26(c)}

Table 6 presents the results for Q.26(c), "The work my SBVPA does enhances my firm's ability to interact with my community in the eight defined community interactions (detailed in Section 2 of the author's thesis)". Table 7 shows the Pearson chi-square contrast test, where it is found differences among the three groups delineated by primary state of operation are accidental (i.e., not statistically significant).

\section{Survey Question 26(d)}

Table 8 presents the results for Q.26(d), "My SBVPA is a forum for operators to network, share knowledge, build trust, and resolve operating environment issues with other operators", and Table 9 shows the Pearson chi-square contrast test, the result of which is statistically significant.

\section{Survey Question 26(e)}

Table 10 presents the results for Q.26(e), “I don't believe that my SBVPA fosters good relationships with government and opposition", and Table 11 shows the Pearson chi-square test, the result of which is found to be accidental (not statistically significant).

\section{Overall Combined Response [Survey Question} 26(a)-(e)]

With regard to the overall (combined) responses to Survey Q.26, Victoria presented with the highest rating, Tasmania with the second-highest rating and Western Australia with the third-highest rating. These results are presented in reverse scale means because one of the questions in this section was asked in the negative sense (i.e., where $1.0=$ Best and $5.0=$ Worst). The results are presented in Table 12. Table 13 presents the one-way ANOVA test, which found that eight out of the 15 contrasts were statistically significant. The data in Table 12 are also presented as a diagram in Figure 1.

\section{DISCUSSION}

Several results materially differ from the mean and deserve mention. First, with regard to the state that secures better contract terms, $52.7 \%$ from Victoria "strongly agreed", whereas the mean for all was $40.1 \%$. This is a material difference from the mean and this result was statistically significant. Second, with regard to the state association enhancing an operator's ability to interact with a community, Victoria received $47.9 \%$ for the sum of "strongly agree" and "agree", followed by Western Australia with $44.2 \%$ and Tasmania with $42.1 \%$. The mean overall was $41.6 \%$. This suggests operators in Victoria believe their service contract enhances their ability to interact with their community more than those in other states. Conversely, the sum of "strongly disagree" and "disagree" for Queensland was $30.4 \%$, which is at material divergence from the mean overall of $15 \%$. This suggests that operators in Queensland generally do not see the endeavours of their SBVPA enhancing their ability to interact with their community. Any implication, however, should be tempered by the neutral response (the sum of “don't agree or disagree”), which secured a high overall mean of $43.1 \%$. This possibly suggests the level of involvement, influence, or dependence (strength of networks, trust, and reciprocity) an operator has with its SBVPA is an issue that respondents may like to give more thought to.

With regard to the SBVPA being a forum for operators to network, share knowledge, and build trust 
Table 6. Cross-Tabulation of Q.26(c) Enhances Ability to Interact With Community $\otimes$ Q.6 Primary State, in Relative (i.e., Percentage) Terms

\begin{tabular}{lllllllll}
\hline & \multicolumn{7}{c}{ Primary state } \\
\cline { 3 - 8 } & & VIC (\%) & NSW (\%) & QLD (\%) & TAS (\%) & SA (\%) & WA (\%) & All \\
\hline Q.26(c) & 1. Strongly agree & 10.9 & 6.1 & .0 & 5.3 & .0 & 7.0 & 7.3 \\
Enhances & 2. Agree & 37.0 & 34.8 & 21.7 & 36.8 & .0 & 37.2 & 34.3 \\
ability to & 3. Don't agree or disagree & 42.4 & 43.9 & 47.8 & 36.8 & 60.0 & 41.9 & 43.1 \\
interact with & 4. Disagree & 7.6 & 15.2 & 21.7 & 21.1 & 20.0 & 11.6 & 12.9 \\
community & 5. Strongly disagree & 2.2 & .0 & 8.7 & .0 & 20.0 & 2.3 & 2.4 \\
Total & & 100.0 & 100.0 & 100.0 & 100.0 & 100.0 & 100.0 & 100.0 \\
\hline
\end{tabular}

Table 7. Pearson Chi-Square Test Pursuant to Table 6

\begin{tabular}{llll}
\hline & Value & df & Asymp. sig. (2-sided) \\
\hline Pearson chi-square & 24.786 & 20 & .210 \\
N of valid cases & 248 & & \\
\hline
\end{tabular}

Table 8. Cross-Tabulation of Q.26(d) Forum to Share Knowledge/Trust, etc., $\otimes$ Q.6 Primary State, in Relative (i.e., Percentage) Terms

\begin{tabular}{lllllllll}
\hline & \multicolumn{7}{c}{ Primary state } \\
\cline { 3 - 8 } & & VIC (\%) & NSW (\%) & QLD (\%) & TAS (\%) & SA (\%) & WA (\%) & All \\
\hline \multirow{2}{*}{$\begin{array}{l}\text { Q.26(d) Share } \\
\text { knowledge/trust, 3. Don't agree or disagree }\end{array}$} & 2. Agree & 13.0 & 16.4 & 39.1 & .0 & 40.0 & 9.1 & 15.1 \\
etc. & 4. Disagree & .0 & 3.0 & 8.7 & 5.0 & .0 & 2.3 & 2.4 \\
& 5. Strongly disagree & 2.2 & .0 & .0 & .0 & .0 & 6.8 & 2.0 \\
\multicolumn{1}{l}{ Total } & 100.0 & 100.0 & 100.0 & 100.0 & 100.0 & 100.0 & 100.0 \\
\hline
\end{tabular}

Table 9. Pearson Chi-Square Test Pursuant to Table 8

\begin{tabular}{llll}
\hline & Value & df & Asymp. sig. (2-sided) \\
\hline Pearson chi-square & 46.601 & 20 & $.001^{* *}$ \\
N of valid cases & 251 & & \\
\hline
\end{tabular}

Note: ${ }^{* *}$ means statistically significant at the $1 \%$ level.

Table 10. Cross-Tabulation of Q.26(e) Does not Foster Good Relationships With Government \& Opposition $\otimes$ Q.6 Primary State, in Relative (i.e., Percentage) Terms

\begin{tabular}{lllllllll}
\hline & \multicolumn{7}{c}{ Primary state } \\
\cline { 3 - 8 } & & VIC (\%) & NSW (\%) & QLD (\%) & TAS (\%) & SA (\%) & WA (\%) & All \\
\hline Q.26(e) Doesn't' 1. Strongly agree & .0 & 1.5 & .0 & .0 & .0 & 2.3 & .8 \\
foster good & 2. Agree & 5.4 & 10.6 & 4.3 & 10.0 & .0 & 2.3 & 6.4 \\
relationships & 3. Don't agree or disagree & 19.6 & 16.7 & 26.1 & 15.0 & 40.0 & 11.6 & 18.1 \\
with & 31.5 & 47.0 & 34.8 & 35.0 & 40.0 & 46.5 & 39.0 \\
government \& & 4. Disagree & 43.5 & 24.2 & 34.8 & 40.0 & 20.0 & 37.2 & 35.7 \\
opposition & 5. Strongly disagree & 100.0 & 100.0 & 100.0 & 100.0 & 100.0 & 100.0 & 100.0 \\
Total & & & & & & & &
\end{tabular}


Table 11. Pearson Chi-Square Test Pursuant to Table 10

\begin{tabular}{llll}
\hline & Value & df & $\begin{array}{l}\text { Asymp. Sig. } \\
(2 \text {-sided })\end{array}$ \\
\hline $\begin{array}{l}\text { Pearson chi-square } \\
\text { N of valid cases }\end{array}$ & 17.812 & 20 & .600 \\
\hline
\end{tabular}

Table 12. Mean Response to Overall (Combined) Q.26(a)-(e) Responses, Resolved by Primary State

\begin{tabular}{llllll}
\hline Primary state & $\mathrm{N}$ & Mean & Std. deviation & Std. error of mean & 95\% Conf. Int. \\
\hline VIC & 92 & 3.935 & .641 & .067 & .134 \\
NSW & 65 & 3.600 & .640 & .079 & .158 \\
QLD & 23 & 3.330 & .623 & .130 & .260 \\
TAS & 19 & 3.842 & .701 & .161 & .322 \\
SA & 5 & 3.120 & .390 & .174 & .348 \\
WA & 43 & 3.837 & .633 & .097 & .194 \\
All & 247 & 3.750 & .667 & .042 & .082 \\
\hline
\end{tabular}

Table 13. One-Way ANOVA Contrast Tests Pursuant to Table 12

\begin{tabular}{lllllll}
\hline Contrast & & Value of contrast & Std. error & $\mathrm{t}$ & $\mathrm{df}$ & Sig. (2-tailed) \\
\hline & [VIC-NSW] & .335 & .104 & 3.226 & 138.018 & $.002^{* *}$ \\
& [VIC-QLD] & .604 & .146 & 4.139 & 34.608 & $.000^{* *}$ \\
& [VIC-TAS] & .093 & .174 & .532 & 24.603 & .599 \\
& [VIC-SA] & .815 & .187 & 4.364 & 5.256 & $.006^{* *}$ \\
& [VIC-WA] & .098 & .117 & .831 & 83.095 & .408 \\
[NSW-QLD] & .270 & .152 & 1.771 & 39.639 & .084 \\
Overall (combined) & [NSW-TAS] & -.242 & .179 & -1.350 & 27.391 & .188 \\
responses to & [NSW-SA] & .480 & .192 & 2.505 & 5.816 & $.047^{*}$ \\
Q.26(a), (b), (c), & [NSW-WA] & -.237 & .125 & -1.898 & 90.817 & .061 \\
(d), and (e) & [QLD-TAS] & -.512 & .207 & -2.476 & 36.441 & $.018^{*}$ \\
& [QLD-SA] & .2104 & .21738 & .968 & 9.154 & .358 \\
& [QLD-WA] & -.5068 & .16177 & -3.133 & 45.718 & $.003^{* *}$ \\
& [TAS-SA] & .7221 & .23721 & 3.044 & 11.804 & $.010^{*}$ \\
& [TAS-WA] & .0049 & .18756 & .026 & 31.543 & .979 \\
\hline
\end{tabular}

Notes: Does not assume equal variances; ${ }^{* *}$ means statistically significant at the $1 \%$ level; ${ }^{*}$ means statistically significant at the $5 \%$ level.

(enhance social capital), Victoria rated highest with 46.7\%, whereas the next highest was Western Australia with $36.4 \%$ and the mean was $35.1 \%$. The Victorian result is at material variance from the other states, and the differences in results between the states are statistically significant.

Concerning the results for Queensland, at the time bus and coach operators were completing this survey (December 2013 to March 2014), Queensland operators had been advised by their state government that it was preparing its response to a Commission of Audit, which contained a recommendation by the auditor to competitively tender all bus-service contracts in that state. This may have caused a significant degree of anxiety among operators in Queensland, which probably caused some of them to think that their SBVPA was less effective than hoped. Later in 2014, the Queensland State Government 


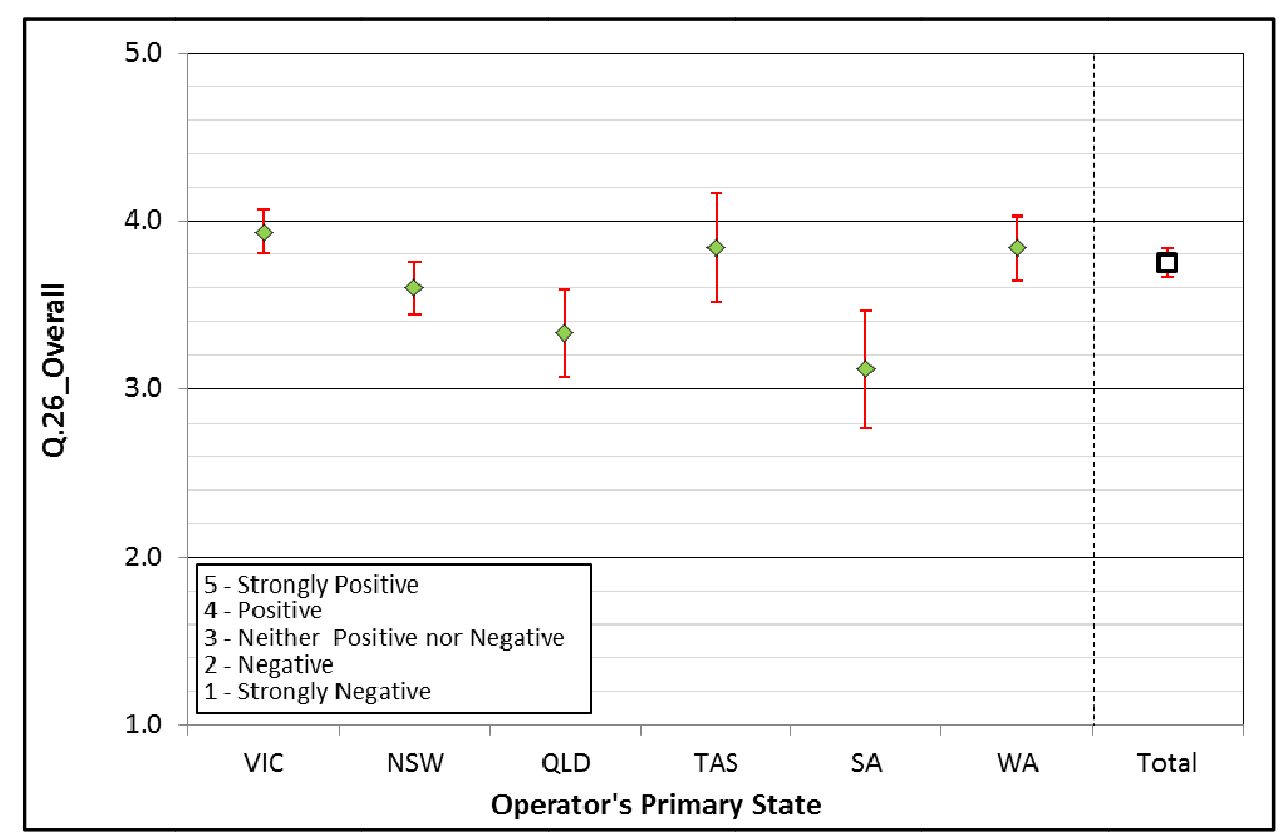

Figure 1. Plot of Data in Table 12.

announced it would accept the Commission of Audit's recommendations and proceed with a competitive tendering project to increase contestability. Then, in early 2015, the new state government declared it would not proceed with the previous government's plan for competitive tendering of bus-service contracts and gave the industry a commitment to negotiate the renewal of incumbent operators' service contracts. Therefore, it is suggested that had operators been asked to complete the Survey in early 2015 (rather than 2014), the results for Queensland concerning social capital linkage may have not have materially diverged from the other states as operators would have had more confidence or certainty of business continuance.

These results reveal that the extent of involvement, dependence, trust, and reciprocity between the member and the association is highest in the state of Victoria. There are many reasons why this may be the case- far too many to comprehensively answer in this paper. However, the author suggests that competitive advantage between the Victorian SBVPA and the other SBVPAs might explain part of it, not all. The Victorian SBVPA has had an open-ended services agreement with the state government authority for some decades. The depth, breadth, and value of that agreement have typically changed as the state government has changed, but the agreement to collaborate remains in place to this day. The authority is party to a service contract with each bus operator and because the Victorian SBVPA is a representative of those operators, the authority and the SBVPA have historically agreed the SBVPA is well placed to assist the bus operators in meeting some or all of their contracted obligations. This sees the SBVPA advocate the views of bus operators to the authority and communicate issues affecting the entire public transport network or parts of the bus network on behalf of bus operators to government. The authority and the SBVPA are obliged to consult with each other and work collaboratively on researching, developing, and implementing initiatives, including but not limited to network accessibility, communications, social issues, safety and security, customer satisfaction, 
operational and technological improvements, fares and ticketing systems and industry productivity improvements. The overarching objective of the document is to improve the level of professional and ethical behaviour of the industry. There are also reciprocal marketing, planning and human resource services that the parties agree to provide to each other.

The Victorian SBVPA is the only one of seven bus and coach voluntary professional associations in Australia to have such an agreement with its state government (personal communications, February 4-6, 2015). Such an agreement requires considerable commitment from both parties involved and frequent engagement on a broad range of issues. This arrangement is evidence of the SBVPA, acting as a conduit to the collective operators and as an agent of government to facilitate collective action. This engenders operator contractual compliance and performance and authority satisfaction with operators. Renewing bus-service contracts with incumbent operators on the basis that they continue to perform is an expectation of most operators who participated in this study and continuance of the bus operation is fundamental to bus operators meeting their economic and non-economic goals. In essence, the SBVPA has mutual obligations: to the operators and the authority. The agreement between the Victorian SBVPA and the authority is essentially a partnership between industry and state to grow social capital. The agreement rests on co-operation.

The concept of government partnering with non-profits is well-established in Australia. Bryce (2012) found contracting with non-profits allows the government to facilitate services to clients in disparate locations and with distinguishable needs. It also allows the government to provide the services with less internal staff, and at the same time, it allows the community to build social capital. The author adds that governments contract with non-profits to emphasise greater trust, lower transaction costs, the higher competence of non-profits and the non-specific nature of contracts. This is sustained by Eversole and Martin (2005: 1) who state:

...policy makers and practitioners are exhorted to ensure that communities are involved and engaged in development processes; to carry out development initiatives in "partnerships" that bridge private and public sectors; and to pursue decentralised governance, participatory development, civil-society-building, and "deepened" democracy to encourage greater involvement in decision making. The underlying theme is... that development should be negotiated rather than imposed.

Partnerships in Australia are normally framed to enable the inclusion of a diverse set of stakeholders in structured development processes to directly address inequities in mainly regional and rural communities. Partnerships in this context are a tripartite of sorts that aim to directly bridge public, private, and civil sectors and increase community engagement. Community engagement is a generic term that can reflect many different levels of intensities of involvement by stakeholders (Eversole and Martin 2005).

In the author's doctoral research project (Lowe 2015), the Victorian SBVPA is found to be the only SBVPA with an agreement in place with its state government authority to co-operatively raise the level of professional and ethical behaviour of the industry. From the survey, Victoria also rated the highest social capital linkage results, the highest sense of community results and the highest value of the mean sum of six community interactions on a per-staff-member basis. It is suggested these results are not a coincidence. These outcomes suggest that the degree of involvement and dependence (or linking social capital) between the operator and the SBVPA contribute to the sustaining of operators' businesses and their ability to contribute to the communities in which they provide transport services. In this context, linking social capital is a social dynamic causing economic benefit. This link should create an acceptance that a successful economy is not simply about physical and financial capital, but also social capital. 


\section{CONCLUSIONS}

This paper discussed the nature of the Australian bus and coach representative environment and the role of SBVPAs. It reviewed the literature associated with memberships to which businesses subscribe for representation and linking social capital and argued that agency theory can explain the member/association dynamic. The results of an Australia-wide survey of bus operators revealed bus operators' views of their SBVPA, with some material divergences from the mean result. It was found that one state, Victoria, possibly had a competitive advantage, due in part to having a partnership-like services agreement with the State Government Authority in place, which facilitates social capital. Thus, it is concluded that an increased determination by governments to contract with non-profit associations, as agents of government, would increase the likelihood of achieving public policy outcomes.

\section{References}

Bell, R. and S. Kilpatrick. 2000. Small Business and Networks: Aspects of Social Capital in a Small Rural Town. Centre for Research and Learning in Regional Australia, University of Tasmania, Launceston, Tasmania.

Bourdieu, P. 1986. "The Forms of Capital.” In Handbook of Theory and Research for the Sociology of Education, edited by J. Richardson. New York, NY: Greenwood Press.

Bryce, H. 2012. Players in the Public Policy Process: Non-Profits as Social Capital and Agents. USA: Palgrave Macmillan.

Bus Association Victoria Inc. 2015. Welcome. Retrieved June 18, 2015 (http://www.busvic.asn.au/public/).

Carney, M. 2005. "Corporate Governance and Competitive Advantage in Family-Controlled Firms.” Entrepreneurship Theory and Practice 29(3):249-265.

Coleman, J. S. 1988. "Social Capital in the Creation of Human Capital.” American Journal of Sociology 94:S95-S120.

Cox, E. and P. Caldwell. 2000. "Making Policy Social.” In Social Capital and Public Policy in Australia, edited by I. Winter. Melbourne, Australia: Australian Institute of Family Studies.

Eisenhardt, K. M. 1989. “Agency Theory: An Assessment and Review." The Academy of Management Review
14(3):488-511.

Eversole, R. and J. Martin. 2005. Participation and Governance in Regional Economic Development: Global Trends in an Australian Context. Aldershot, England: Ashgate.

Fayez, S., A. O’Loughlin, and A. Zutshi. 2012. “Agency Theory and Supply Chain Management: A Structured Literature Review." Supply Chain Management: An International Journal 75(5):556-570.

Foote, K. 2015. Member Care Visitation Report. Bus Association Victoria Inc.

Green, G. 1996. "Social Capital and Entrepreneurship: Bridging the Family and Community." Presented at the Cornell University Conference on Entrepreneurial Families-Building Bridges, March 17-19, New York. Retrieved (http://fambiz.com/Orgs/Cornell/articles/real/ green.cfm).

Hart, O. and J. Moore. 1990. "Property Rights and the Nature of the firm." Journal of Political Economy 98(6):1119-1158.

Jarvis, P. 1987. The Sociology of Adult and Continuing Education. London, UK: Croom-Helm.

Jensen, M. C. and W. H. Meckling. 1976. "Theory of the Firm: Managerial Behaviour, Agency Costs and Ownership Structure.” Journal of Financial Economics 3(4):305-360.

Laursen, L., F. Masciarelli, and A. Prencipe. 2012. "Regions Matter: How Localised Social Capital Affects Innovation and External Knowledge Acquisition.” Organisation Science 23(1):177-193.

Lester, R. and A. Cannella. 2006. "Inter-Organisational Familiness: How Family Firms Use Interlocking Directorates to Build Community-Level Social Capital.” Entrepreneurship Theory and Practice 30(6):755-775.

Lowe, C. 2015. "The Social Externalities of Bus and Coach Operators: How Governance Affects Community Prosperity.” Draft thesis. Melbourne, Victoria.

Mitnick, B. 1973. "Fiduciary Rationality and Public Policy: The Theory of Agency and Some Consequences." Presented at the Annual Meeting of the American Political Science Association, New Orleans, LA.

Murphy, D. 2005. "Understanding the Complexities of Private Family Firms: An Empirical Investigation.” Family Business Review 18(2):123-133.

Parada, M., M. Nordqvist, and A. Gimeno. 2010. "Institutionalising the Family Business: The Role of Professional Associations in Fostering a Change of Values.” Family Business Review 23(4):355-372.

Portes, A. 1998. "Social Capital: Its Origins and Applications in Modern Sociology.” Annual Review of Sociology 24:1-24.

Putnam, R. 1995. "Bowling Alone: America’s Declining Social Capital.” Journal of Democracy 6(1):5-8. 
Ritchie, B., C. S. Brindley, and N. Armstrong. 2008. "Risk Assessment and Relationship Management: Practical Approach to Supply Chain Risk Management.” International Journal of Agile Systems and Management 3(3-4):228-247.

Ross, S. A. 1973. "The Economic Theory of Agency: The Principal's Problem.” The American Economic Review 63(2):134-139.

Shapiro, S. P. 1987. "The Social Control of Impersonal Trust.” The American Journal of Sociology 93(3):623-658.

—. 2005. "Agency Theory.” Annual Review of Sociology 31:263-284.
Winter, I., ed. 2000. Social Capital and Public Policy in Australia. Melbourne, Australia: Australian Institute of Family Studies.

\section{Bio}

Christopher Lowe, M.B.A. (C.S.U., 2006), Ph.D. candidate at Monash Sustainability Institute, Melbourne, Australia, executive director, Bus Association Victoria Inc. (Australia); research fields: social externalities, governance, family businesses, bus industry, and voluntary professional associations.

\section{APPENDIX}

\section{Section 3}

The Role of the State-based Bus Industry Voluntary Professional Association

25. What impact does membership of your state-based voluntary professional association have on your ability to run your business? (Please tick one box).

$\square$ Very positive impact

Generally positive impact

$\square$ Neither negative nor positive impact

$\square$ Generally negative impact

Very negative impact

26. To measure your views of the state-based voluntary professional association in your primary state, please read the statements below and circle one response.

\begin{tabular}{|l|l|l|l|l|l|l|}
\hline & $\begin{array}{l}\text { Strongly } \\
\text { agree }\end{array}$ & Agree & $\begin{array}{l}\text { Don't agree } \\
\text { or disagree }\end{array}$ & Disagree & $\begin{array}{l}\text { Strongly } \\
\text { disagree }\end{array}$ \\
\hline A & $\begin{array}{l}\text { My state-based voluntary professional association } \\
\text { gives my firm access to buying power that helps my } \\
\text { firm compete }\end{array}$ & 1 & 3 & 5 \\
\hline B & $\begin{array}{l}\text { My state-based voluntary professional association } \\
\text { helps my firm secure better contract terms and } \\
\text { conditions }\end{array}$ & 2 & 3 & 4 & 5 \\
\hline C & $\begin{array}{l}\text { The work my state-based voluntary professional } \\
\text { association does enhances my firm's ability to } \\
\text { interact with my community in the ways detailed in } \\
\text { Section 2 }\end{array}$ & 2 & 3 & 5 \\
\hline D & $\begin{array}{l}\text { My state-based voluntary professional association is a } \\
\text { forum for operators to network, share knowledge, } \\
\text { build trust and resolve operating environment issues } \\
\text { with other operators }\end{array}$ & $\begin{array}{l}\text { I don't believe that my state-based voluntary } \\
\text { professional association fosters good relationships } \\
\text { with government and opposition }\end{array}$ & 2 & 3 & 5 \\
\hline
\end{tabular}

